Information Management and Business Review (ISSN 2220-3796)

Vol. 7, No. 4, pp. 98-107, August 2015

\title{
Macroeconomic News and Price Discovery in Indonesian Government Bond Market
}

\author{
Dahlia Ervina \\ University of Indonesia, Depok, West Java, Indonesia \\ dahlia.ervina@ui.ac.id
}

\begin{abstract}
The study of macroeconomic news impact on government bond gets little attention, especially in emerging markets. Andritzky et al. (2007) and Nowak et al. (2011) study this impact for some emerging countries, but little attention given to Asian countries. The question about whether macroeconomic news have impacts on government bond is important, considering the large amount of government bonds outstanding in Indonesia and the importance of regulation to maintain the stabilization of bond price. This research use daily returns of Indonesian government bond benchmark series over five-year period to investigate the impact of domestic and global macroeconomic news announcements. We study the relationship using event study approach. Following common literature we use surprise component of macroeconomic news announcements, which will be defined as the difference between market expectation and the actual release of the macroeconomic news. We use economic forecast survey conducted by Bloomberg as the proxy of market expectations needed to calculate domestic (Indonesia) and global (US) macroeconomic news announcements surprises. We find that, for bond returns, surprises of global macroeconomic news announcements is more important than domestic ones, especially for recent years, while both surprises of global and domestic macroeconomic news announcements affect bond returns volatility.
\end{abstract}

Keyword: Bond pricing, Bond returns, Macroeconomic news announcements, emerging market

\section{Introduction}

Returns of investments cannot be guaranteed, even for fixed income securities such as bonds. Even though the future cash streams of a bond is known, there is no $100 \%$ guarantee that all of the cash streams will be received by the investor, because there is credit risk which may lead the default of the payment. This is also applied to government bonds, despite its use as risk free asset in many financial calculations. History said there were some countries that failed to pay their debts. Investors estimate the risk using information. When an investor gets new information, he will adjust his expectation toward the investment and give a new value (price) to the investment. Investors who invest in a corporate stocks or bonds will value both financial and non-financial information of the corporate, which is the investment's underlying value. It will be the same 
with investors who invest in government bonds. They will value financial and non-financial information about the government of the countries so they can adjust their expectation toward the bonds.

Many studies examine the relationship between domestic or global macroeconomic factors and government bond yield or spread, such as Rozada and Yeyati (2008) or Erba et al. (2013). The studies find that the relationship is significant. These studies usually use a long period data as macroeconomic data usually available for monthly at the shortest and yearly at the longest. They cannot capture the immediate reaction of the market when the new information arrived. When new information arrived, investors immediately adjust their expectations and at that time the new value or price of the investments is being formed. This paper tries to capture the impact of the macroeconomic news announcements on Indonesian government bond price and volatility. Previous studies, which are few, mainly focus in advanced markets. Studies in emerging markets by Andritzky et al. (2007) and Nowak et al. (2011) did not include Indonesia in their sample. Indonesian government bond size has increased tremendously after the economy crisis in 1998 and the secondary market is developing fast, show the importance of studying Indonesian government bond price and volatility. The paper is organized in six parts - introduction, review of literature, data and data resources, methodology, results and discussion, and conclusions and recommendations.

\section{Literature Review}

Literature about impact of macroeconomic news announcements mainly focus on stocks or currencies returns instead of bonds or government bonds. And many of those researches focus on advanced markets and very few on emerging markets. Early researches capture the impact of macroeconomic news announcements on bond returns by comparing returns on days when there were macroeconomic news announcements and days when there wasn't, such as Fleming and Remolona (1999) and Andritzky et al. (2007). Recent studies use 'surprise' effect of macroeconomic news announcements and use forecast survey from Money Market Services (MMS) International or Bloomberg as proxy of market expectation, such as Balduzzi et al. (2001), Goeij and Marquering (2006), Brenner et al. (2009), Nowak et al. (2011), and Paiardini (2014).

Balduzzi et al. (2001), using intraday data of US Treasury Bill and Treasury Note, find that several announcements affects bond price, but in different manner according to maturity of the bond. Rigobon and Sack (2006) use new technique to handle noise in news found higher significance of the news on US Treasury bond returns. Brenner et al. (2009) study the impact of macroeconomic news on US Financial markets find that the news surprises have significant impact on all assets type including government bond, and especially sensitive for 'good' news surprise. Outside US, Paiardini (2014) study the effects of macroeconomic news on Italian government bond. The study use domestic, neighboring countries, regional and global macroeconomic news surprises. The results show 25 of 68 news types has significant impact on Italian government bond 
returns. Only 1 domestic news is significant and mostly US news has significant impact. Andritzky et al. (2007) and Nowak et al. (2011) study macroeconomic news effects on emerging bond markets. Andritzky et al. (2007), using GARCH $(1,1)$ and dummy variables to indicate days with news, find that domestic macroeconomic news has no significant effect on emerging bond markets spreads at the mean level, but the US interest rate news has. Nowak et al. (2011) find that global and regional macroeconomic news are the same important as the domestic news. US macroeconomic news that has large surprise found to have large effect compare to same surprise size of domestic news.

Several studies also try to capture the news effect on bond returns volatility. Balduzzi et al. (2001) find that news has significant and persistence increases on bond returns volatility. Goeij and Marquering (2006) find that macroeconomic news surprises have significant impact on daily returns of US Treasury bonds. This impact on volatility is difference between several news types as some news has longer impact and other have shorter impact. Brenner et al. (2009) find that news have significant impact and that conditional bond return volatility increase before the news released and decrease afterward. In emerging markets, both Andritzky et al. (2007) and Nowak et al. (2011) find that news have significant impact on market volatility and Nowak et al. (2011) also find that the volatility is more drawn-out compared to advanced markets. Most previous studies indicates the significance of news on government bond returns. Studies outside US always use US news as global news indicator, and find that the news significantly affects government bond markets outside US. Most news types also has significance on government bond return volatility, with emerging market volatility tend to be more drawn-out compared to mature markets.

Data and Data Resources: This study using daily average price in secondary market to get daily returns on benchmark series of Indonesian government bond. Average price is used because there is no data information about the hour and minute when the transaction done. Transactions mainly done through over the counter and then reported to the Bank Indonesia as the central registry for all Indonesian government bond. The daily return is calculated as follow:

$R_{t}=\frac{\left(P_{t}-P_{t-1}\right)}{P_{t-1}}$

Where $R_{t}$ is daily return at time $t$ of a benchmark series of Indonesian government bond. $P_{t}$ is price of a benchmark series of Indonesian government bond at time $t . P_{t-1}$ is price of a benchmark series of Indonesian government bond at time $t-1$.

The new information in macroeconomic news is proxied by 'surprise' following common literature by Balduzzi et al. (2001), Nowak et al. (2011) and Paiardini (2014). This surprise is the difference between actual macroeconomic news and the expectation of the market. For the expectation of the market I use Bloomberg forecast survey to market analysts which is also used in many previous studies such as Nowak et 
al. (2011) and Paiardini (2014). This survey results is released prior to the scheduled date of the news. The surprise is calculated as follow:

$S_{k, t}=\frac{\text { Actual }_{k, t}-\text { Expectation }_{k, t}}{\sigma_{k}}$

Where $S_{k, t}$ is surprise macroeconomic news $k$ at time $t . \sigma_{k}$ is standard deviation of forecast error of macroeconomic news $k$. We use standardized surprise following Balduzzi et al. (2001) so all news surprises can be comparable and have same units of measure.

Data of daily Indonesian government bond transactions was obtained from Bank Indonesia-Scriptless Securities Settlement System (BI-SSSS). The data is all transactions of benchmark series of Indonesia government bond for the period 2010-2014. There 21 series with breakdown 5 series for year 2010, 4 series for year 2011, 4 series for year 2012, 4 series for year 2013 and 4 series for year 2014. We use 1 year transactions data for each series. Although the data is available for longer period, but the transaction activities will be different when a series appointed as benchmark or not, so the data after 1 year is not comparable. Data of news dates, actual macroeconomic news, and market analyst survey was obtained from Bloomberg. There are 9 macroeconomic news used referred to previous literature which include 4 domestic news and 5 global news. Domestic macroeconomic news used are Indonesian CPI, Indonesian trade balance, Bank Indonesia interest rate and Indonesian GDP. Global macroeconomic news used are US CPI, US GDP, US current balance, US retail sales and US PPI (producer price index). These variables are used based on the consistent significance results on previous studies, especially in emerging markets.

\section{Methodology}

This paper attempts to examine the impact of surprises from macroeconomic news on Indonesian government bond price and volatility. Using the time series technique, tests of stationarity and multicollinearity needed. After the data become stationary and free of multicollinearity, equation (4.1) is estimated. Residuals are tested for autocorrelation and heterokedasticity. If there is autocorrelation, model AR (autoregressive), MA (moving average) or ARMA is used. If there is heterokedasticity, 'White Heteroskedasticity-Consistent Standard Errors \& Covariance' is used to avoid bias on standard errors estimations. Following Nowak et al. (2011) and Paiardini (2014) we use linier regression to estimate the impact of news surprises on Indonesian government bond returns.

$R_{t}=\beta_{0}+\sum_{i=1}^{I} \beta_{i} R_{t-i}+\sum_{k=1}^{K} \beta_{k} S_{k, t}+u_{t}$

Where $R_{t}$ is daily return at time $t$ of a benchmark series of Indonesian government bond, $R_{t-1}$ is lagged $t-1$ return of a benchmark series of Indonesian government bond $S_{k, t}$ is surprise macroeconomic news $k$ at time $t$. 
To know the impact of the macroeconomic news on returns volatility of Indonesian government bond, we apply GARCH $(1,1)$ following Andritzky et al. (2007), but we use surprise variables instead of dummy variable in the equation. GARCH $(1,1)$ was developed by Bollerslev (1986) to allow the conditional variance to depend on its previous own lags. We use 'Bollerslev-Wooldridge Heterokedasticity Constant Covariance' if the residuals is not following normal distribution, to avoid bias on standard errors estimations.

$$
\begin{aligned}
& R_{t}=\beta_{0}+\sum_{i=1}^{I} \beta_{i} R_{t-i}+\sum_{k=1}^{K} \beta_{k} S_{k, t}+u_{t} \\
& u_{t} \sim N\left(0, h_{t}\right) \\
& h_{t}=\alpha_{0}+\alpha_{1} u_{t-1}^{2}+\alpha_{2} h_{t-1}+\sum_{k=1}^{K} \alpha_{k} S_{k, t}+\varepsilon_{t}
\end{aligned}
$$

Where $h_{t}$ is daily returns variance of a benchmark series of Indonesian government bond, $h_{t-1}$ is one lagged daily returns variance of a benchmark series of Indonesian government bond and $u_{t-1}^{2}$ is one lagged of residual squared.

\section{Results and Discussion}

The result for estimation of equation (4.1) can be found below for Indonesian government bonds period 2014. The estimates for Bank Indonesia rate is not applicable because for the year 2014, there is no surprise or the actual BI rate is the same with the market expectations for scheduled news. The regression results for year 2014 in Table 1 show that no domestic macroeconomic news have significant impact on bond returns, but

\begin{tabular}{|c|c|c|c|c|c|c|c|c|}
\hline \multirow[b]{2}{*}{ Series No\# } & \multicolumn{8}{|l|}{2014} \\
\hline & FR0068 & & FR0069 & & FR0070 & & FR0071 & \\
\hline Constant & 0.000174 & & 0.000015 & & 0.000142 & & 0.000228 & \\
\hline CPI Indonesia & $(0.003314)$ & & $(0.000327)$ & & $(0.002449)$ & & $(0.002830)$ & \\
\hline T.Balance Indonesia & $(0.002587)$ & & 0.000174 & & $(0.000543)$ & & $(0.000545)$ & \\
\hline BI Rate Indonesia & NA & & NA & & NA & & NA & \\
\hline GDP Indonesia & $(0.006612)$ & & $(0.000117)$ & & $(0.000843)$ & & $(0.011602)$ & \\
\hline CPI US & $(0.005071)$ & $* *$ & $(0.001484)$ & $* *$ & $(0.004400)$ & $* * *$ & $(0.003496)$ & \\
\hline GDP US & 0.000115 & & 0.000398 & & 0.001360 & & 0.001852 & \\
\hline Current Balance US & $(0.013265)$ & $* * *$ & $(0.002505)$ & $*$ & $(0.007853)$ & $* *$ & $(0.012157)$ & $*$ \\
\hline Retail Sales US & $(0.006973)$ & $* * *$ & $(0.001147)$ & $*$ & $(0.003810)$ & $* *$ & $(0.004130)$ & $* *$ \\
\hline PPI US & 0.004022 & $*$ & 0.000673 & & 0.003656 & $* *$ & 0.001010 & \\
\hline
\end{tabular}
global macroeconomic news dominantly affect bond returns.

Table 1: Surprise macroeconomic news response on Indonesia government bond period 2014

This table reports the regression results for each series and news of eq. (4.1) for period 2014

${ }^{*} p<0.01 \quad * * p<0.05 \quad * * * p<0.1$ 
Table 2: Surprise macroeconomic news response on Indonesia government bond returns

\begin{tabular}{|c|c|c|c|c|c|c|c|c|c|c|c|c|c|c|c|c|c|c|c|c|c|}
\hline \multirow[b]{2}{*}{ Series FR00 No\# } & \multicolumn{5}{|c|}{2010} & \multicolumn{4}{|c|}{2011} & \multicolumn{4}{|c|}{2012} & \multicolumn{4}{|c|}{2013} & \multicolumn{4}{|c|}{2014} \\
\hline & 27 & 31 & 40 & 50 & 52 & 53 & 54 & 55 & 56 & 58 & 59 & 60 & 61 & 63 & 64 & 65 & 66 & 68 & 69 & 70 & 71 \\
\hline Constant & & & & & & & * & & & & & & & & & & & & & & \\
\hline CPI Indonesia & $(* *)$ & & & & & & & $\left({ }^{* * *}\right)$ & & & & & & & & & $* *$ & & & & \\
\hline T.Balance.Indonesia & $* * *$ & & & & & & & & & & & & & & $\left({ }^{* *}\right)$ & & & & & & \\
\hline BI Rate Indonesia & & & & & & & & & & $\left({ }^{* * *}\right)$ & $\left(^{(* *)}\right.$ & & $\left(^{* * *}\right)$ & & & & & & & & \\
\hline \multicolumn{22}{|l|}{ GDP Indonesia } \\
\hline CPI US & & & & & & & & & & & & & & & & & & $\left({ }^{* *}\right)$ & $(* *)$ & $(* * *)$ & \\
\hline \multicolumn{22}{|l|}{ GDP US } \\
\hline Current Balance US & & & & $(* * *)$ & $* * *$ & & & & & & & & & & $\left({ }^{* * *}\right)$ & & $(*)$ & $(* * *)$ & $(*)$ & $\left(^{(* *}\right)$ & $(*)$ \\
\hline Retail Sales US & & & & & & & & & & & & & & & & & & $(* * *)$ & $(*)$ & $\left({ }^{* *}\right)$ & $(* *)$ \\
\hline PPI US & & & & & $(* *)$ & & & & & & & & & & & $* * *$ & & $*$ & & $* *$ & \\
\hline
\end{tabular}

This table reports the regression results for each series and news of eq. (4.1) for period 2010-2014

${ }^{*} p<0.01 \quad{ }^{* *} p<0.05 \quad{ }^{* * *} p<0.1 \quad$ () negative value coefficients 
It is not the same case every year. The summary of regression results for year 2010-2014 is in Table 2. The coefficients number is not provided due to space limitation, but the summary is enough to show that the domestic news impact is very little, except for the surprise of BI rate news. The global news have no or little impact between 2010-2012 and starting to have impact in 2013, and become dominant in 2014.

These results in line with the share of Indonesia government bonds owned by foreign investors as can be seen in following figure.

Figure 1: Foreign investor shares of Indonesian government bonds

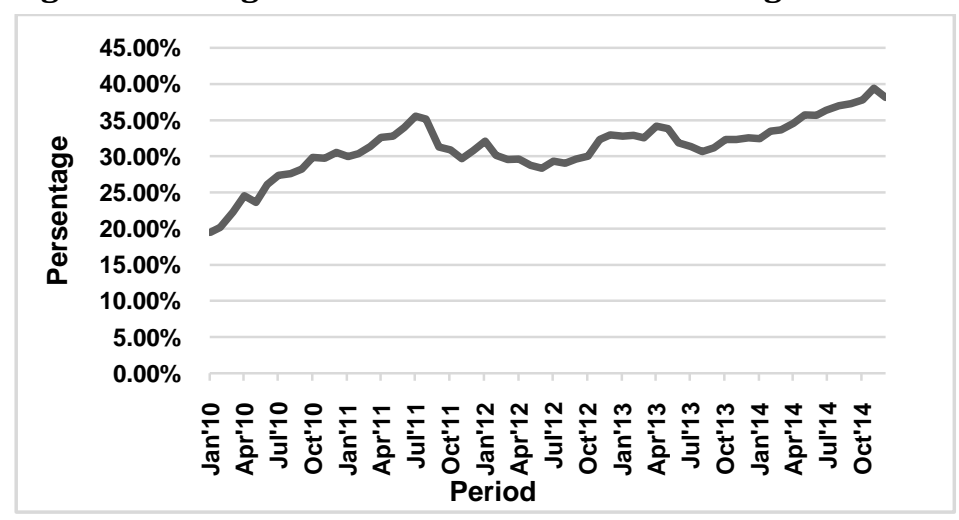

Sources: :http//www.djppr.kemenkeu.go.id

The foreign investor shares is quiet stagnant with tendency to decrease in 2011-2012, and starting to increase in mid 2013 until the end of 2014. This explain the dominance of global macroeconomic news impact on Indonesian government bond returns in 2014. The results for estimations of equation (4.2) can be seen in Table 3 which show that both domestic and global news have impact on bond returns volatility, but with inconsistent manner over time. For example PPI US news surprises which lessen the volatility in 2011, increase the volatility in 2012-2013, then going back lessen the volatility in 2014. This means the market response is changing overtime in processing the new information. The ARCH (1) coefficients are mostly not significant means the variance is not affected by past residual squared. All GARCH (1) coefficients are significant means the variance is affected by past variances. 
Table 3: Surprise macroeconomic news response on Indonesia government bond returns volatility

\begin{tabular}{|c|c|c|c|c|c|c|c|c|c|c|c|c|c|c|c|c|c|c|c|c|c|}
\hline \multirow[b]{2}{*}{ Series FR00 No\# } & \multicolumn{5}{|c|}{2010} & \multicolumn{4}{|c|}{2011} & \multicolumn{4}{|c|}{2012} & \multicolumn{4}{|c|}{2013} & \multicolumn{4}{|c|}{2014} \\
\hline & 27 & 31 & 40 & 50 & 52 & 53 & 54 & 55 & 56 & 58 & 59 & 60 & 61 & 63 & 64 & 65 & 66 & 68 & 69 & 70 & 71 \\
\hline \multicolumn{22}{|l|}{ Variance Level } \\
\hline $\mathrm{ARCH}(1)$ & & * & & & & * & ** & & & & & & & & & & & & & ** & * \\
\hline GARCH (1) & $* * *$ & $* * *$ & $* * *$ & $* * *$ & ** & $* * *$ & $* * *$ & $* * *$ & $* *$ & $* * *$ & $* * *$ & $* * *$ & $* * *$ & $* * *$ & $* * *$ & $* * *$ & $* * *$ & $* *$ & $* * *$ & $* * *$ & $* * *$ \\
\hline Constant & $* * *$ & $* * *$ & $* * *$ & $* * *$ & * & $* * *$ & $* * *$ & $* * *$ & $* * *$ & $* * *$ & $* * *$ & *** & $* * *$ & $* * *$ & $* * *$ & $* * *$ & $* * *$ & $* *$ & $* * *$ & $* * *$ & $* * *$ \\
\hline CPI Indonesia & & $(* * *)$ & & $(* * *)$ & $(*)$ & & & $* * *$ & $*$ & & & $*$ & $* *$ & & $(* * *)$ & & $(* * *)$ & & & & \\
\hline T.Balance Indonesia & & & $(* * *)$ & $\left(^{*}\right)$ & & & & & & * & & * & * & & $(* * *)$ & $* * *$ & $* * *$ & & $* * *$ & $* * *$ & $* * *$ \\
\hline BI Rate Indonesia & & & & & & *** & $* * *$ & *** & $* * *$ & $*$ & $* * *$ & *** & *** & $\left({ }^{* * *}\right)$ & $(* * *)$ & $(* * *)$ & $(* * *)$ & & & & \\
\hline GDP Indonesia & $(* *)$ & $(* * *)$ & $* * *$ & $* * *$ & & $\left({ }^{* * *}\right)$ & $(* * *)$ & $(* * *)$ & $(* *)$ & $\left(^{*}\right)$ & $(* * *)$ & $(* * *)$ & $\left({ }^{* * *}\right)$ & *** & *** & $* * *$ & $* * *$ & & & *** & * \\
\hline CPI US & $* * *$ & *** & $* * *$ & $* * *$ & *** & $\left({ }^{* * *}\right)$ & & $\left({ }^{* * *}\right)$ & & $* *$ & *** & *** & * & & *** & & & $(* * *)$ & & $(* * *)$ & $(* * *)$ \\
\hline GDP US & $(* *)$ & & $(* * *)$ & & & *** & & *** & ** & & $(* * *)$ & & & & *** & & $* * *$ & & & $\left({ }^{* *}\right)$ & $(* * *)$ \\
\hline Current Balance US & $(* * *)$ & & & & $(* * *)$ & $(* * *)$ & $(* * *)$ & $(* * *)$ & $(* * *)$ & $* *$ & $* * *$ & ** & ** & & $(* * *)$ & $(* *)$ & $(* * *)$ & & & & \\
\hline Retail Sales US & & & $*$ & & & $(* * *)$ & $(* *)$ & & & & $* * *$ & ** & $* * *$ & $(* *)$ & $*$ & $(* * *)$ & $(* * *)$ & $* * *$ & $* * *$ & $* * *$ & $* * *$ \\
\hline PPI US & & & & & $(* * *)$ & $(* * *)$ & $(* * *)$ & $(* * *)$ & $(* *)$ & & $* * *$ & & $* * *$ & $* *$ & $* *$ & $* * *$ & $* *$ & $(* * *)$ & $(* * *)$ & $(* * *)$ & $(* * *)$ \\
\hline
\end{tabular}

This table reports the GARCH $(1,1)$ results for each series of eq. (4.2) for period 2010-2014

${ }^{*} p<0.01 \quad * * p<0.05 \quad * * * p<0.1 \quad$ () negative value coefficients 
There were 2 unscheduled news of BI rate which surprised market in 2013 and 2014. I have re-run the estimation with data that include the unscheduled news surprises. The results show that there is no significant changes for 2013 results, but for 2014, the news affect 2 of 4 benchmark bond series returns significantly. As for volatility, the BI rate news surprises significantly affect the returns volatility in 2013 and 2014.

\section{Conclusion and Recommendations}

This paper study impact of the macroeconomic news on Indonesian government bond price and volatility. Using daily returns of benchmark series of Indonesian government bond period 2010-2014 as dependent variable and macroeconomic news surprises as independent variables, we find that domestic news impact is very little, except for the surprise of BI rate news. The global news have no or little impact between 2010-2012 and starting to have impact in 2013, and become dominant in 2014. While for the impact on volatility, the results show that both domestic and global news have impact on bond returns volatility, but with inconsistent manner over time. This means the market response is changing overtime in processing the new information. These results are useful for regulators, investors, and academicians. The suggestion for the regulators are to be aware of macroeconomic news that affect the government bond market, so that immediate actions can be taken if the market about to become unstable. It is also suggested to create and maintain the regulations for foreign investors' participants in the market. The regulators also need to encourage investors to do transactions in the exchange than through OTC as this may lead to better system and data of secondary market transactions. Future researches can be done by using intraday data with information about precise time the transactions happen, which is currently not available, to see more comprehensively about the instantaneous market reactions to macroeconomic news surprises.

\section{References}

Andritzky, J. R., Bannister, G. J. \& Tamirisa, N. T. (2007). The impact of macroeconomic announcements on emerging market bonds. Emerging Markets Review, 8, 20-37

Balduzzi, P., Elton, E. J. \& Green, T. C. (2001). Economic news and bond prices: Evidence from the U.S. Treasury market. The Journal of Financial and Quantitative Analysis, 36(04), 523-543

Bollerslev, T. (1986). Generalized autoregressive conditional heteroskedasticity. Journal of Econometrics, 31, 307-327

Brenner, M., Pasquariello, P. \& Subrahmanyam, M. (2009). On the volatility and comovement of U.S. financial markets around macroeconomic news announcements. The Journal of Financial and Quantitative Analysis, 44 (06), 1265-1289

Brooks, C. (2008). Introductory Econometrics for Finance ( $2^{\text {nd }}$ ed). New York: Cambridge University Press. 
Directorate General of Financing and Risk Management. (2015). Statistics: The position of Surat Berharga Negara. May 26, 2015 http://www.djppr.kemenkeu.go.id/page/load/22

Erba, S. D., Hausmann, R. \& Panizza, U. (2013). Debt levels, debt composition, and sovereign spreads in emerging and advanced economies. Oxford Review of Economic Policy, 29, 518-547

Fleming, M. J. \& Remolona, E. M. (1999). Price formation and liquidity in the U.S. Treasury market: The response to public information. The Journal of Finance, 54(5), 1901-1915.

Goeij, P. \& Marquering, W. (2006). Macroeconomic announcements and asymmetric volatility in bond returns. Journal of Banking \& Finance, 30, 2659-2680.

Nowak, S., Andritzky, J., Jobst, A. \& Tamirisa, N. (2011). Macroeconomic fundamentals, price discovery, and volatility dynamics in emerging bond markets. Journal of Banking \& Finance, 35, 2584-2597

Paiardini, P. (2014). The impact of economic news on bond prices: Evidence from the MTS platform. Journal of Banking \& Finance, 49, 302-322.

Rigobon, R. \& Sack, B. (2006). Noisy macroeconomic announcements, monetary policy, and asset prices. NBER Working Paper 12420 Available online at http://www.nber.org/papers/w12420.

Rozada, M. G. \& Yeyati, E. L. (2008). Global Factors and Emerging Market Spreads. Economic Journal, 118, 1917-1936.

Republic of Indonesia. (2002). Undang-Undang Republik Indonesia Nomor 24 Tahun 2002 about Surat Utang Negara. Lembaran Negara Republik Indonesia Tahun 2002, Nomor 110. Sekretariat Negara. Jakarta. 